\title{
Debts, Money, Intellectual Property, Data and the Concept of Dematerialised Property
}

\author{
by Andreas Rahmatian*
}

\begin{abstract}
Debts, (electronic) money, intellectual property, and, in principle, data and digitised objects (if ownership rights are to be recognised for these), can be conceptualised as versions of the general principle of dematerialised property. This article discusses first the concept of dematerialised property and its application to debts, money and intellectual property. Then it deals with the idea of ownership of data within traditional property concepts.
\end{abstract}

\begin{abstract}
While data ownership can theoretically be accommodated fairly easily within the framework of dematerialised property, there are several reasons, both theoretical and from a legal policy perspective, which make the introduction of data ownership modelled upon conventional (intellectual) property rights problematic.
\end{abstract}

Keywords: dematerialised property; money creation; intellectual property theory; data ownership

\section{(c) 2020 Andreas Rahmatian}

Everybody may disseminate this article by electronic means and make it available for download under the terms and conditions of the Digital Peer Publishing Licence (DPPL). A copy of the license text may be obtained at http://nbn-resolving. de/urn:nbn:de:0009-dppl-v3-en8.

Recommended citation: Andreas Rahmatian, Debts, Money, Intellectual Property, Data and the Concept of Dematerialised Property, 11 (2020) JIPITEC 186 para 1.

\section{A. Introduction}

1 The modern economy relies more and more on intangible assets, whether financial assets (ultimately a form of debt, particularly in its most significant version: money), or intellectual property and data, while the production and sale of physical goods and assets becomes less important. Some commentators seem to suggest that the law of property struggles when it tries to keep up with these developments. In fact, an underlying concept of modern property law systems appears well-equipped to meet these new challenges, and although lawyers hardly address this concept specifically, it is in reality impliedly accepted: the concept of dematerialised property. This concept will be discussed in the following article, with some of its most important practical applications: debts, money, intellectual property, and, at least potentially, data and digitised objects.
2 First, one has to explain how the term 'property' is used and understood in the following discussion. The English word 'property', also in its technicallegal meaning, is ambiguous, ${ }^{1}$ and at the start of the discussion it is necessary to define the term 'property' as follows: 'property' means (a) assets or wherewithal or 'patrimonium' of a person, (b) property right, (c) property object or 'thing' or res (the latter term will be used in the following), and, finally, (d) 'ownership', although this meaning is imprecise and should better be avoided. ${ }^{2}$

* Professor of Commercial Law at the School of Law of the University of Glasgow, UK.

1 See also Lutz-Christian Wolff, 'The relationship between contract law and property law', (2020) 49(1) Common Law World Review, 34-36.

2 Andreas Rahmatian, Lord Kames. Legal and Social Theorist (Edinburgh University Press, 2015) 221-224. 
Relevant for the following discussion are meanings (b) and (c) - property right and property object. It will become clear that in the concept of dematerialised property ${ }^{3}$ 'property right' and 'property object' are in fact interchangeable terms.

\section{B. The concept of dematerialised property}

3 Different legal systems have different definitions of property rights, but historically property objects or 'things' in law have generally been regarded as being physical things, at least initially. In German law, property or things (Sachen) are indeed only physical objects ( $\$ 90$ German Civil Code, BGB), ${ }^{4}$ but that forces Germany to recognise debts (Forderungen) ${ }^{5}$ and intellectual property rights as quasi-property in effect, ${ }^{6}$ so that functionally this narrow definition of property, which seems to have developed rather fortuitously and can be traced back to a particular romanist interpretation of property by the German

3 See Andreas Rahmatian, 'Intellectual Property and the Concept of Dematerialised Property', in: Sue Bright (ed.), Modern Studies in Property Law, vol. 6 (Hart Publishing, 2011) 361-383, at 361; Rahmatian, Lord Kames (n 2) 228-230; Andreas Rahmatian, Credit and Creed. A Critical Legal Theory of Money (Routledge, 2020) 6-18.

$4 \S 90$ BGB: 'Sachen im Sinne des Gesetzes sind nur körperliche Gegenstände.' Similar Dutch Civil Code (Burgerlijk Wetboek), art 5:1: ownership refers to corporeal objects.

5 This becomes apparent in the situation of the assignment of debts or claims (Forderungsabtretung), where the attribution to a creditor is changed, which requires the application of a quasi-proprietarian speciality principle, like with actual property rights, see e.g. Dieter Medicus, Schuldrecht I. Allgemeiner Teil, 14th ed. (C. H. Beck, 2003) 350, for Germany. Transferability is generally an indication of the existence of a property right, at least functionally, see for English law, Kevin Gray and Susan Francis Gray, Elements of Land Law, $5^{\text {th }}$ ed. (Oxford University Press, 2009) 96-98.

6 In the case of intellectual property rights, these are Immaterialgüterrechte (literally, 'rights of incorporeal goods'), see for Germany and the German author's rights law which, due to its strong personal component, is not regarded as a true property right, Vogel in Gerhard Schricker (ed.) Urheberrecht. Kommentar, 4th ed. (C. H. Beck, 2010) 58, n 26 : 'quasi-dingliches Recht', on the historical development, ibid at 86, n 109; Schulze in Thomas Dreier and Gernot Schulze, Urheberrechtsgesetz. Kommentar, 5th ed. (C. H. Beck, 2015) 79, n 11: the notion that the work that is protected by the author's right ('copyright') is made concrete or is realised in the physical piece of work (ibid), already hints at the idea of dematerialised property, see below.
Historical School in the nineteenth century, ${ }^{7}$ is really upheld in practice. The treatment of licences in German author's rights law (Urheberrecht) makes the interpretation of such property-like sui generis rights as 'quasi-property' particularly apparent. ${ }^{8}$ More practical is a wide definition of property, for example in Austria's § 285 of the General Civil Code (ABGB), which stipulates that everything that is different from the human being and serves the use of man, is a thing or res in law. ${ }^{9}$ A similar approach is taken in other jurisdictions, for example in France, ${ }^{10}$ England $^{11}$ or Scotland. ${ }^{12}$ Accordingly, property objects can be corporeal as well as incorporeal, or, in the terminology of English law, tangible, intangible and purely intangible. 'Pure intangibles' denotes property created as legal concepts, for example debts or intellectual property rights, while 'intangibles' can also mean intangible objects of the physical world, such as gas or electricity. ${ }^{13}$ Although theoretically corporeal (both moveable and immoveable) and incorporeal property are only sub-categories of the same legal concept of property (unitary concept of property), the different legal systems are bound to take account of the (non-)physicality of a res and to provide adequate provisions, for example in relation to the acquisition of possession or ownership or

7 Maximilian Haedicke, Rechtskauf und Rechtsmängelhaftung (Mohr Siebeck, 2003) 35.

8 While the author's right itself and its exploitation rights (Verwertungsrechte) are not transferable in German law (see German § 29 (1) Urheberrechtsgesetz 1965), the licences (Nutzungsrechte) granted under an existing author's right are transferable, with author's consent (which cannot be withheld in bad faith, German § 34 (1) Urheberrechtsgesetz 1965), see Schricker/Loewenheim in Schricker (n 6) 581, n 50.

$9 \S 285$ ABGB: 'Alles, was von der Person unterschieden ist, und zum Gebrauche der Menschen dient, wird im rechtlichen Sinne eine Sache genannt.'

10 François Terré and Philippe Simler, Droit civil: Les biens, $9^{\text {th }}$ ed. (Dalloz, 2014) 43.

11 E.g. Michael Bridge, Personal Property Law, $4^{\text {rd }}$ ed. (Oxford University Press, 2015) 13-16: choses in possession (tangible chattels), choses in action (debts), (pure) intangibles.

12 Kenneth G. C. Reid (and contributors), The Law of Property in Scotland (Butterworths, 1996) 17, 22, para. 11 and note 4, para. 16.

13 Bridge (n 11) 13, 16. In reality the distinction between 'pure intangibles' and 'intangibles' is often not strictly made. 
the grant of security rights over property, which reflect the tangible or intangible nature of the res in question..$^{14}$ That problem will not be discussed in the present context.

4 On this basis, one can develop the property concept further. Property is not primarily a connection between a person and an object, but a legal relationship between persons with regard to things (relational concept of property). ${ }^{15}$ The law determines what this proprietary relationship consists of, by essentially ordering a specific behaviour towards persons in respect of things which makes them 'their' things. This is commonly referred to as the property right (or 'real right' ${ }^{16}$ ), the subjective exclusive right to a res, enforceable erga omnes ${ }^{17}$ (in English law: 'a property right binds the world') ${ }^{18}$ different from, and independent of, an underlying contractual relationship that would only bind the contracting parties. ${ }^{19}$ The property right of ownership, being the most extensive property right, ${ }^{20}$ is enforced by the owner against, for example, the trespasser or the thief in relation to a res, such as

14 For an ownership transfer, physical delivery is possible in relation to moveable property (or, if unsuitable, through symbols), or change of registration in case of land/immoveable property, or information of the debtor (intimation) to perfect the transfer of a claim/debt in case of an assignment (depending on the jurisdiction in question).

15 The relational concept of property is not a new theory, although some sociologically informed authors seem to suggest this, but can be traced back to the eighteenth century at least, see in particular Immanuel Kant, Die Metaphysik der Sitten, Wilhelm Weischedel (ed.), (Werkausgabe Band VIII) (Suhrkamp Taschenbuch Verlag, 1977) 371-372. For more discussion, see e.g. Rahmatian, Lord Kames (n 2) 225-226. It is rather a truism that property rights are ultimately enforceable only against persons, see e.g. Reid (n 12) 8, para. 3.

16 Here the term 'real' has to be understood in its original Latin meaning, from which also the word res ('thing') derives. The words 'real estate' and the technical term for land/immoveable property in English law, 'real property', are examples of that.

17 Franz Bydlinski, System und Prinzipien des Privatrechts (Springer Verlag, 1996) 315-318.

E. g. Bridge (n 11) 1-4.

Bydlinski (n 17) 171-172, 174.

There are of course more limited, or subordinate real rights, such as the pledge, the mortgage or real security or hypothec (the exact terminology depends on the jurisdiction in question), the easement or servitude (such as a right of way) and so on. This is not discussed further. a plot of land or a watch as an instance of that res (on the idea of the 'instance', see immediately below). ${ }^{21}$ Thus 'property' is the creature of the law; there are no 'natural' property rights, ${ }^{22}$ in contrast to some natural law theories of property. The exclusive rights to a res, the property rights or real rights, actually create the property or res by protecting it erga omnes. There are evidently physical objects in the natural world, either as natural or as man-made products, like an apple or a car, but they are only recognised by, and incorporated in, the system of the law by (potentially) ${ }^{23}$ attaching property rights to them: only then they are objects or 'things' for the purpose of the law, otherwise they are non-existent for the law. This is therefore an entirely constructivist idea of property: it is the law that makes the object to a thing or res in law and therefore 'constructs' it as 'real' from a legal perspective. The physical existence of an object in the natural world is not legally imperative.

5 Consequently, the res is a legal construct that is 'filled' by physical objects of whichever kind, being a field, a car, or a book. These are concrete instances of the res, that is, the legal conception that turns physical objects into 'property', or more precisely, property objects in law, a process which one can call, somewhat unattractively, 'propertisation'. The res as such is only res because of the property rights attached to it: by turning physical objects into res they incorporate the object of the natural world (the 'is') into the normative world of the law (the 'ought'). In fact, the physical object of property only represents, but does not constitute, the res which is the legal concept of 'property object'. This physical object operates as a 'social reifier' of the res, being a material representation of an abstract legal concept. It becomes clear again that the physicality of the object representing the legal notion of the res is conceptually unnecessary. Therefore, the res may be represented by a physical thing, but equally it

21 In the present context, the nature or content of real rights, such as ownership, is not discussed. For the 'internal side' of real rights, see e.g. Rahmatian, Dematerialised Property (n 3) 366-367.

22 This follows ultimately Jeremy Bentham, see Jeremy Bentham, 'Principles of the Civil Code', in: The Theory of Legislation, $7^{\text {th }}$ ed. (R. Hildreth, trans.) (Kegan Paul, Trench, Trübner, 1891) 88-236, at 111-113, and David Hume, see David Hume, A Treatise of Human Nature, book 3, part 2, L. A. Selby-Bigge (ed.) (Clarendon Press, 1960) 491.

23 This comprises cases of res nullius where currently there is no property right attached in a given case but could be established through finding, occupation etc. 
can be made concrete in the form of a non-physical legal concept itself, the most practical example being intellectual property rights. ${ }^{24}$

6 This is the idea of dematerialised property: the 'ought' of the res need not be materialised as an 'is' in form of a physical object as a social reifier that may indicate socially the adhering legal real right - this is in fact insignificant. Human behavioural patterns creating property rights may be supported by physical objects - for example the social act of delivery of a thing (traditio) for denoting the transfer of ownership in that thing to a new owner - but the actual real right (including attribution changes of that right) and the res it thereby creates through the proprietary protection of that very res are independent of any physicality. As the real right creates the res, the normative terms 'property right' and 'property object' are conceptually interchangeable. With regard to intellectual property, this is obvious: the terms 'intellectual property right' and 'intellectual property' are indeed equivalent, also in practical use. As far as corporeal property is concerned, the expression 'property right' denotes more the real right to the thing, while the term 'property' (in the specific meaning of 'thing') emphasises the property object represented by a physical thing, such as a chattel. Conceptually, however, right and 'thing' (here understood as the legal concept of the res) are substitutable also in the case of tangible property, as explained before.

7 This idea of normative dematerialisation makes the following argument, often found in property theory, in fact irrelevant: that intellectual property rights - and also data, for that matter ${ }^{25}$ - are nonrivalrous goods, unlike physical property, and are therefore not actual property. The legal question is not whether the consumption of the good by one individual does (not) prevent or reduce availability of the good for consumption by others, but whether there is a normative creation of 'property', or a res, and that applies to tangible and intangible property alike: in this way, the rivalrous nature is normatively ordered, not legally acknowledged in line with existing physical circumstances. ${ }^{26}$ In copyright, protection is not granted for 'ideas' that are non-

24 Rahmatian, Dematerialised Property (n 3) 371.

25 Francesco Banterle, 'Data Ownership in the Data Economy: A European Dilemma', in: T.-E. Synodinou et al. (eds), EU Internet Law in the Digital Era (Springer International Publishing, 2020) 199-225, at 213; Thomas Hoeren and Philip Bitter, 'Data ownership is dead: long live data ownership', (2018) 40 (6) European Intellectual Property Review, 347.

26 Andreas Rahmatian, Copyright and Creativity: The Making of Property Rights in Creative Works (Edward Elgar Publishing, 2011) 103, in relation to copyright. rivalrous, but for distinct individual expressions of the author who uses and shapes these ideas, and it is their expression and the legal protection by copyright attached to them, which creates normatively the rivalrous good (if one wants to adhere to this concept for pure intangibles at all). In this regard the same would have to apply for data, so the problem of proprietary protection of data cannot be solved on this basis.

\section{Applications of dematerialised property l: debts, (electronic) money and intellectual property rights}

8 A typical application of dematerialised property are also legal concepts, so that a physical object as an instance of the res to which the property right relates (and which the property right by way of this relation creates) is actually not possible. This is the case of debts and intellectual property rights in particular.

9 The debt is an entirely legal creature with no physical appearance in nature. Some legal systems deny the debt proprietary quality (Germany, §§ 90, 903 BGB), but functionally the debt is unquestionably property of the creditor (thus more precisely 'claim', from the creditor's perspective ${ }^{27}$ which also materialises in the assignability of the debt to a new creditor. Transferability (in principle, but there may be transfer prohibitions) indicates the quality as property. ${ }^{28}$ As no physicality exists, the transfer or assignment cannot be made public by way of overt acts that denote and make apparent the change of attribution ${ }^{29}$ in form of a physical handing over or change of possession (delivery, traditio), so that legal systems insist on the compliance with certain formalities to perfect or make effective the assignment (for example intimation/information of the debtor of the assignment - the individual jurisdictions differ here). These formalities perform an evidentiary and a channelling function, to speak

27 English legal language does not make a distinction between debt (debtor's side of the obligation) and claim (creditor's side), as for example German law and French law do, compare Rahmatian, Credit and Creed (n 3) 13.

28 For English law, see Gray and Gray (n 5) 96-98.

29 Or 'ownership' of the debt/claim, although some legal systems, for example Germany and Austria, avoid this term and talk about 'Rechtszuständigkeit' (attribution or allocation of the debt/claim) but functionally this is of course ownership, that is, the most unlimited form of allocation. 
with Fuller. ${ }^{30}$ However, debts can be, and are often, reified in form of a corporeal reifier, that is, a paper that denotes, proves, and often even creates, the debt it represents. This is the case of negotiable instruments. The transfer of the debt can thus be made corporeal and visualised, and, particularly with bills of exchange, the formalised transfer of the debt (negotiation) carries further rights in connection with, and as a result of, that transfer (especially secondary liability). ${ }^{31}$

10 A special form of debt, where transferability is its very essence and purpose, is money. This becomes apparent if one looks at the money creation process. Bank money is discussed first, since bank money is today by far the more important form of money compared to cash (about $97 \%$ of all circulating money is bank money), ${ }^{32}$ and since bank money is historically older than the modern system of cash that replaced the old forms of commodity money and commodity-backed money of the nineteenth and early twentieth centuries. Bank money is created when a bank grants a loan to its customer. The bank credits the customer's account with the loan sum, so that the bank, as account provider, is debtor of the customer in respect of the loan sum, while the customer, as borrower, is insofar creditor, as if the customer had paid funds (e.g. cash) into his account with the bank. At the same time, the bank, as lender, is creditor to the customer who as the borrower has to repay the loan debt to the bank. The money, in form of the granted loan sum in the bank account (bank money), is therefore a circulating debt (or circulating credit from the creditor's perspective): it appears as an asset of the customer-borrower in his account and can therefore be transferred to a third party for the payment of goods or services obtained from this third party. That third party, upon receipt of the bank money in his account, can use this money for the payment of a fourth party - so the debt or money circulates in the economy. However, independent of that circulation the borrower has to repay the loan granted, invariably together with interest. ${ }^{33}$ Money, being circulating debt or credit, and at the same time loan debt, is therefore a janiform debt

30 Lon L. Fuller, 'Consideration and Form', (1941) 41 (5) Columbia Law Review, 800-801.

31 E.g. M. A. Clarke, R. J. A. Hooley, R. J. C. Munday, L. S. Sealy, A. M. Tettenborn, P. G. Turner, Commercial Law: Text, Cases, and Materials (5 $5^{\text {th }}$ edn) (Oxford University Press, 2017) 691, 699, for English law.

32 Bank of England (McLeay, Michael, Radia, Amar and Thomas, Ryland), 'Money Creation in the Modern Economy', (2014) Quarterly Bulletin Q1, 15.

33 Rahmatian, Credit and Creed (n 3) 66-69, with further discussion and references. or a janiform money-debt res (property object): it is (a) a loan debt which stays between bank as lender and customer as borrower, (b) it circulates as debt in the economy because it is used for payment to discharge money debts (typically as a result of sales contracts) and thereby operates as, and is, money. Gradual repayment of the loan debt reduces and extinguishes the debt and destroys money which the debt constitutes. ${ }^{34}$ Obviously the repayment of a loan only destroys money in relation to the amount of money circulating in the economy as a whole; it does not destroy the particular circulating sum of money which was created on the grant of that loan in question, because the loan debt and the circulating debt are separated from one another as from the first payment of the borrower out of his account to the third party. ${ }^{35}$

11 Cash, as the most important form of central bank money, is conceptually not different to commercial bank money or simply 'bank money', only that the circulating debt is issued by a central bank and effectively not redeemable, for example in gold, since the gold standard has long been abolished. Furthermore, the debt is represented by a banknote, technically a promissory note or IOU (the English banknotes are still styled as promissory notes), so that the creditor is the holder of the banknote (a bearer instrument) and the debtor the central bank (which is in turn the creditor of the state or government at whose behest the central bank issues cash). The banknote therefore represents both the moveable property-res (as the physical paper) and the debt-res (as the money this note denotes). The debtres (money) that is represented by the banknote as a social reifier and (technically) negotiable instrument is practically nugatory, because claiming payment of the debt embodied in the banknote entitles only to payment by other banknotes, and necessarily in full and final satisfaction of the debt, so that the debt is self-referential. ${ }^{36}$ While in the case of cash the money debt-res is represented by a banknote as a social reifier or physical object that is (especially historically) a negotiable instrument, there is hardly any representation of the bank money-debt res: the representation of the bank money debt effectively amounts to its creation: a written line of numbers on a bank account statement. ${ }^{37}$

34 Bank of England (n 32) 16.

35 Rahmatian, Credit and Creed (n 3) 67, 72, 81-83, 201.

Rahmatian, Credit and Creed (n 3) 63-64. There are very rare cases where the debt represented by a banknote is not nugatory, see ibid at 64 . 
12 Bank money is in reality electronic money today. The times when bank money was recorded in the paper books of the bank, for example the money created following the grant of a loan ('fountain pen money') are long gone. Bank money is recorded or created by way of input of computer data. It is also possible to replace physical cash or paper money by digital cash or 'e-money', and projects of this kind already exist. ${ }^{38}$ Besides, there are private digital currencies, such as Bitcoin or Ethernet. What the quality of these types of money is from a legal (not technological) perspective, depends particularly on the origin of that money (that is, who is the issuer), and is a complicated matter. ${ }^{39}$ However, relevant in this context is that, according to the concept of dematerialised property, it is possible that the res is represented by a physical object (cash), but this is not necessary (bank money, electronic money).

13 Intellectual property rights are not debts. With financial assets, such as money, a debtor is required to create the asset: no debtor - no creditor - no asset. Hence the complete repayment of a money debt as a result of a loan destroys money ${ }^{40}$ because it extinguishes the debt which money constitutes. Intellectual property is not a financial asset, because there is no debtor who would otherwise be indispensable for the creation and the maintenance of this form of res. Intellectual property rights are rather 'real assets', therefore conceptually related to tangible assets (not to financial assets), that is, to res represented by physical objects. However, while in case of tangible property a physical object that represents a res reifies the res directly (e.g. land, a car), intellectual property rights as necessarily incorporeal legal concepts can only have an indirect reifier in form of a physical object. Copyright illustrates that nicely. The physical copy of a book, for example, represents, as a tangible reifier, directly the res of the corporeal property, and that is what the buyer of the book obtains as the new owner after a sale of the book to him. The copy of the book also represents indirectly the res of the copyright in the text, the literary work which the text constitutes. This copyright-property in the res is not transferred with the sale of the physical copy. Thus the physical object, the copy of the book, is direct reifier of the moveable property res and at the same time indirect reifier of the copyright-res. ${ }^{41}$ Here the situation of

38 Rahmatian, Credit and Creed (n 3) 21, 24.

39 Further discussion in Rahmatian, Credit and Creed (n 3) 94103, 150, with further references.

40 Bank of England (n 32) 16, and above.

41 Compare Code de la Propriété Intellectuelle 1992, art. L. 1113: 'La propriété incorporelle définie par l'article L. 111-1 est indépendante de la propriété de l'objet matériel.' intellectual property is conceptually similar to the banknote, as we have seen before. This is even more accentuated in the case of the visual arts. While text, or literary works can exist in an intangible form (the oral traditions of epic poetry are such an example), visual arts require a tangible expression for their very existence: the oil on canvas is reifier of the legal concept 'moveable property' and at the same time for the legal concept 'intellectual property' in the form 'artistic work' ${ }^{42}$ Hence the copyright system of the UK requires recording or fixation for copyright protection for literary, dramatic and musical works, but not explicitly for artistic works, ${ }^{43}$ because an artistic work cannot come into existence without fixation. The case of music is more complicated because the musical score, for example, does not necessarily represent the musical work as such, so that the refier of the copyright res directed at the musical work is further removed from the res it represents. ${ }^{44}$

14 With patents the intellectual property (res) is represented by the specific text of the patent as granted, particularly the claims which create the patent-res, not by a machine incorporating the patent (if such a machine exists already). ${ }^{45}$ It could not be otherwise because the delineation and extent of the property right cannot be provided by a representing physical object, as would be in case of tangible property. As the patent is an abstract legal concept, it is the law as the originator of the concept which must create and define the extent and content of the patent through the written text of the patent specification. For that the law cannot rely on the qualities of an existing physical object in the natural world. (Registered) trade marks are now regarded as property in their own right, not merely as signifiers of goodwill of a business. Thus a trade mark is indirect refier of the res 'business goodwill' (origin, quality and communication functions of the trade mark) and direct reifier of the res 'sign' in form of a graphical representation (in case of the classical pictorial mark or a word). ${ }^{46}$

42 Rahmatian, Dematerialised Property (n 3) 17.

43 UK Copyright, Designs and Patents Act 1988, s. 3 (2).

44 Rahmatian, Copyright and Creativity (n 26) 18.

45 Rahmatian, Dematerialised Property (n 3) 375-376.

46 Rahmatian, Dematerialised Property (n 3) 378. 


\section{Applications of dematerialised property Il: data, digitised objects}

\section{Data}

15 Having discussed the established examples of intangible and tangible property as versions of the res, one can now consider phenomena where their proprietary nature is much less certain. The pure and strict application of the conception of dematerialised property does not pose any particular difficulties when data and digitised objects are to be included as further forms of dematerialised property. The problem is rather whether the effects of such an incorporation are desirable from a legal policy perspective. ${ }^{47}$

16 In a modern, service industry-oriented economy it is advantageous to give up on the materiality or physicality of an object as a prerequisite for qualifying as property. The concept of dematerialised property emphasises the constructive nature of the legal idea of property: it is not a material object from which property rights flow, but the abstract legal concept of property rights rather brings property or 'things' in law into existence, so that any physicality is legally irrelevant. Accordingly, data can also be defined as 'res' by the law, and become (incorporeal) property, similar to debts and intellectual property rights.

17 However, a complete incorporation of data as just another form of property into the existing property regime of private law systems can cause some difficulties. ${ }^{48}$ The obvious problem is the practical effect of the property right to which data are

47 See Hoeren and Bitter ( $n$ 25) 347-348. See also, from the perspective of German law, and its narrow concept of 'thing' (Sache) in $\S 90$ BGB, Jürgen Kühling, Florian Sackmann, „Rechte an Daten: Regulierungsbedarf aus Sicht des Verbraucherschutzes?", Berlin: Verbraucherzentrale Bundesverband e.V., (2018) 7-8, available at: <https://www.vzbv.de/sites/default/files/ downloads/2018/11/26/18-11-01_gutachten_kuehlingsackmann-rechte-an-daten.pdf> (visited 28/05/2020).

48 A discussion of this problem from a US-American perspective by Jorge L. Contreras, 'The false promise of health data ownership', (2019) 94(4) New York University Law Review, 634-636, especially the test whether an intangible could be property, according to Kremen v. Cohen, 337 F.3d 1024, at 1030 (9th Cir. 2003): 'First, there must be an interest capable of precise definition; second, it must be capable of exclusive possession or control; and third, the putative owner must have established a legitimate claim to exclusivity.' (According to the Court, domain names would satisfy these criteria). supposed to be subjected to: (i) what exactly is the property object (the res, or its reification in a given concrete example), (ii) what is the content of the real right in relation to data? (iii) who is the property right allocated to? (iv) how can this allocation be changed, that is, how can ownership in the data be transferred? The following discussion will consider these aspects in turn.

18 (i) While with conventional property, also incorporeal property, the property object can usually be made out quite clearly (a copyright in a literary work, a debt arising from a contract of sale), with data the matter is less clear. Unlike specific incorporeal things, data are rarely single individual data or objects, but data sets, large amounts of data, which are a kind of universitas rerum, ${ }^{49}$ thus an object of property which consists of many separate parts forming a whole, such as a flock of sheep, a library or a business. In contrast to these usual examples, an amount of data normally and quickly grows, and, furthermore, can be duplicated and copied as true unaltered digital copies of the original, so that the extent of a given universitas rerum of data cannot be ascertained clearly at a given time. It may also be difficult to separate and distinguish clearly one universitas rerum or set of data from another set of data, but that would be necessary for an unambiguous allocation to a certain right-holder or owner. A herd of cattle could not be multiplied quickly, and not at all through 'electronic' copying, and every cow could be ascertained as being part of a certain universitas rerum by way of earmarks or branding (hence the 'maverick (cattle) laws' in some States of the USA). ${ }^{50}$ Therefore an analysis of the possible proprietary quality of data which seeks to establish parallels with universitas rerum, such as an enterprise or even a herd of animals, must probably fail. The separate parts of this universitas rerum do not grow in an unregulated arbitrary manner and particularly do not reproduce as identical copies like digital copies of data. In addition, a herd of animals can be delimited and remains ascertainable because the animals keep together because of their natural instincts. Data obviously do not have these qualities.

49 'Gesamtsache' in German legal language, see e.g. § 302 Austrian ABGB. The German BGB does not have this term.

50 A maverick cow was an unbranded cow so that it could not be allocated to an owner. 'Maverick laws' would provide sales, ownership allocation rules and access to land rights in relation to such unbranded cattle, for example the Wyoming Legislative Assembly's 1884 'Act to Provide for the Gathering and Sale of Mavericks', see James Winton Eaton, 'The Wyoming Stock Growers Association's Treatment of Nonmember Cattlemen during the 1880s', (1984) 58 (1) Agricultural History, 71. 
19 Furthermore, the incorporeal nature of data prevents possession as it can be exercised with regard to physical things. Possession would also assist in defining the object of property in question. However, the equivalent of 'possession of a right' ('Rechtsbesitz' in German legal language) could be implemented by exercising the right. Change of possession and the connected act of publicity as an indication of change of ownership is not available with incorporeal data either, nor can an apparent authority be founded in relation to data, being an 'appearance of having the right' ('Rechtsschein' in German legal language), the central reason for the justification of the exception to the nemo plus iuris transferre potest quam ipse habet or nemo dat-rule. ${ }^{51}$ A transfer of data rights (and data as objects - again the res appears to be created by the real rights) would realistically have to be subjected to particular formality rules (see below under iv).

20 It is therefore not clear which object the data ownership right would really refer to at a given moment, in contrast to, say, a specific claim to deliver or to pay the price in a particular sales contract which is directed as a specifiable object of property. This could also become problematic if one envisages the possibility of subordinate real rights of security over data. If data are to be property then at least theoretically they could be pledged or subjected to another security right as any moveable or also incorporeal property: many jurisdictions have the assignment in security, and patents or trade marks can be mortgaged or equivalent security rights granted over them. From a legal policy perspective, it would be advisable to prohibit the grant of security rights over data altogether, not only because it potentially undermines the intended protection of the data subject, but also because it avoids the problem of the principle of speciality for the grant of security rights in civil law jurisdictions (English law does not have such a restriction, as the institute of the floating charge shows). ${ }^{52}$ According to this speciality principle (Spezialitätsgrundsatz in German legal language), a creation of a pledge over things in their entirety, without identifying a specific res to which the pledge shall attach, is impossible..$^{53}$ However, German law, for example, allows a security in collective entities of moveables, but whether data would be able to benefit from this

51 E.g. Andreas Rahmatian, 'A Comparison of German Moveable Property Law and English Personal Property Law', (2008) 3 (1) Journal of Comparative Law, 225, with further references.

52 The floating charge is only available for companies, see John Birds, Daniel Attenborough, Mark Leiser, Matteo Solinas, Michael R Varney, Zinian Zhang, Boyle \& Birds' Company Law, $10^{\text {th }}$ ed. (LexisNexis, 2019), 305.

53 See e.g. Rahmatian, German Moveable Property (n 51) 230-231, with further references. wider interpretation of the speciality principle is very doubtful, given that the pledge and similar security rights are based on the physicality of the property and on possession which become naturally impossible in the case of data.

21 One also has to distinguish between the data carrier (a CD-ROM, USB-stick etc.) and the data on it. The problem resembles that of copyright where the ownership transfer of the physical work does not entail the transfer of the copyright in the work, and physical object and copyright follow different ownership and property transfer rules (those of moveable property and of intellectual property, respectively). ${ }^{54}$ This also applies to works of art, thus the purchase of a painting does not include the transfer of the artist's copyright to the buyer of the painting. However, this idea had not been taken for granted but developed over the years. For example, the old Austrian Author's Rights Act of 1846 contained a presumption of the transfer of the author's right together with the purchase and ownership transfer of works of art. ${ }^{55}$

22 In a similar vein, the data carrier follows the usual rules of moveable property, while data, if conceptualised as property, are subjected to their own property rules, and transfer of ownership of one does not automatically entail transfer of ownership of the other. The discussion in English law and Scots law about whether software is to be regarded as 'goods' within the meaning of the Sale of Goods Act $1979^{56}$ or not illustrates this. A recent decision of the English Court of Appeal, ${ }^{57}$ following, inter alia, earlier Scottish authority, ${ }^{58}$ decided that the supply of software without tangible media is not to be regarded as a sale of 'goods'. An earlier English case $^{59}$ clarified that a computer disc is within the definition of 'goods', while a program, of itself, is not. The statutory definition of 'goods' in the Sale of Goods Act which excludes 'choses in action', that is,

$54 \quad$ See above under 3.

$55 \S 11$ of Allerhöchstes Patent vom 19. October 1846 zum Schutze des literarischen und artistischen Eigenthums gegen unbefugte Veröffentlichung, Nachdruck und Nachbildung, Justizgesetzsammlung 1846, Nr. 992, S. 375.

56 Sale of Goods Act 1979, s. 61 (1): 'goods' includes all personal chattels other than things in action and money.

57 Computer Associates UK Ltd. v. The Software Incubator Ltd. [2018] EWCA Civ 518, [2018] ECC 25, especially paras. 30-34.

58 Beta Computers (Europe) Ltd v Adobe Systems (Europe) Ltd 1996 S.L.T. 604.

59 St Albans DC v International Computers Ltd [1996] 4 All E.R. 481; [1997] F.S.R 251. 
debts, aims at the corporality of the res (or its refier, respectively) for such a distinction: in the case of a physical object the Sale of Goods Act applies; in the case of software (being also a particular form of data), which could be seen as analogous to debts and other incorporeal property, copyright applies. ${ }^{60}$ However, one has to distinguish between what the objective of copyright protection is and what a sui generis protection of data aims at, even where the phenomenon in question is both data and copyright work, such as with computer programmes (below under (iii)).

23 (ii) All real rights, particularly the most extensive and most important one, ownership, can be analysed as having an internal side (broadly, the right to use) and an external side (broadly, the right to exclude). ${ }^{61}$ Intellectual property rights as intangible property rights can be used as guidance for the application of these principles to data to ascertain the content of data ownership. In the case of intellectual property rights, the right to use materialises particularly in the right to use or exploit in accordance with the nature and the rules of the intellectual property right in question, for example with regard to copyright/author's right, the use manifests itself in the 'acts restricted by copyright' (in the UK) ${ }^{62}$ or the 'Verwertungsrechte' (in Germany). ${ }^{63}$ Furthermore, an essential aspect of the right to use is the right to assign and to license. ${ }^{64}$ The right to exclude manifests itself in the infringement provisions which mirror the acts restricted by the intellectual property right.

24 Theoretically, the incorporeal property 'data' could have a similar regime. The practical realisation however requires a more adjusted definition. The most important rights in relation to data are (i) access to (and information about) personal data, and (ii) controlling the use, ${ }^{65}$ processing and transfer of, personal data by the person from whom these personal data have been collected. The General Data Protection Regulation (GDPR) provides such rights

60 In relation to the contractual (not proprietary) side the UK Consumer Rights Act 2015, ss. 33 et seq. applies now when the supply of 'digital content' (data which are produced and supplied in digital form) is involved, provided the contract is concluded between a trader and a consumer (ibid s. 2).

61 Compare $\S 903$ BGB for a standard definition of the ownership right.

62 UK Copyright, Designs and Patents Act 1988, ss. 16 et seq.

$63 \S \S 15$ et seq. German Urheberrechtsgesetz 1965.

64 For copyright in the UK and other jurisdictions, see e.g. Rahmatian, Copyright and Creativity (n 26) 201-208.

65 That includes the erasure of data. already in arts. $13,15,17,18$ and 20 in particular. ${ }^{66}$ However, these rights are specific rights granted by public law (administrative law) and not instances of property ownership under private law (ius utendi, fruendi, abutendi): thus a right which has not specifically been granted by law (typically a statute) cannot be assumed to exist. In contrast, the private law approach to ownership considers ownership as the widest possible property right ${ }^{67}$ of which the scope is only restricted by specific public law (e.g. building regulations) and private law rules (e.g. rights of way in land law, permitted acts/defences in intellectual property law), but otherwise unlimited and not in need of legislative intervention that identifies the existence or exercise of a concrete right of exploitation. Even if data ownership were introduced in the form of Immaterialgüterrechte ('rights of incorporeal goods', an attractive option in Germany for systemic reasons), it would structurally still be an individual quasi-ownership right of a citizen under private law for the purpose of use and exclusion: this is a functional (dynamic) interpretation of ownership which does not adhere (statically) to any materiality of a property object. ${ }^{68}$ Any public law regulation is therefore necessarily more casuistic and at the risk of becoming obsolete soon if not updated regularly. The private law/ property approach is invariably more elastic, but less exact which makes a constitutional law assessment of proportionality and of the balance of conflicting interests in respect of human rights less predictable (e.g. privacy against collection, use and transfer of data). ${ }^{69}$ However, the practical result, for example in relation to sensitive health data, may well be the

66 Regulation (EU) 2016/679 of the European Parliament and of the Council of 27 April 2016 on the protection of natural persons with regard to the processing of personal data and on the free movement of such data, and repealing Directive 95/46/EC (General Data Protection Regulation), 4. 5. 2016 OJ L 119/1.

67 E.g. Antony M. Honoré, 'Ownership' in: Antony G. Guest (ed.), Oxford Essays in Jurisprudence (First Series) (Oxford University Press, 1961) 107-147, at 108, 112. See also the legal definitions in $\S 903$ German BGB, § 354 Austrian ABGB, Art 544 French Code Civil, Art 641 Swiss ZGB.

68 Karl-Heinz Fezer, Repräsentatives Dateneigentum: Ein zivilgesellschaftliches Bürgerrecht (Konrad-AdenauerStiftung, 2018) 14, 48 available at: <https://www.kas.de/c/ document_library/get_file?uuid=f828a351-a2f6-11c1-b7201aa08eaccff9\&groupId=252038> (visited 29/05/2020).

69 Such a proportionality test also appears in Directive 95/46/ EC (General Data Protection Regulation), art. 6 (1) (f). 
same, whether achieved through public law control by the data subject or private law ownership by the data owner. ${ }^{70}$

25 (iii) An additional problem of an alignment of data ownership with traditional property ownership rules is that the creator of the property object as the 'instantiation' or reification (if any) of the res, the data, and the person entitled to the data (ownership) are not necessarily the same, as would normally be the case with the rules of accession and specification in moveable property ${ }^{71}$ or with the rules of authorship in copyright. ${ }^{72}$ Generally, ownership requires an owner, the beneficiary of the real right. In the case of data ownership, the 'owner' of the data entitled to the rights that this ownership confers is less clear-cut than, for example, with regard to copyright ownership.

26 One could assume that copyright could provide a good role model for data ownership allocation, the identification of the actual 'owner' of data collected or generated. Both apply to incorporeal property objects. However, what makes the issue murkier is that data can actually be copyright-property objects themselves if they are part of a computer programme or a database. ${ }^{73}$ The fact that a phenomenon or a physical entity or appearance can fall into two different regimes of regulation is nothing new. Within intellectual property for example, a typical overlap is the copyright protection which a figurative trade mark obtains as an artistic work. ${ }^{74}$ Trade mark and copyright protection may apply simultaneously, but the protection mechanisms have different objectives (protection of the artistic work the trade mark's design constitutes, protection of the business goodwill the trade mark denotes). In relation to the copy of a book, this copy is reifier of the tangible moveable property and of the literary

70 Barbara J. Evans, 'Much Ado about Data Ownership', (2011) 25 Harvard Journal of Law and Technology, 74.

71 See, e.g., the comparison between the UK and Germany in relation to accession by Rahmatian, German Moveable Property (n 51) 227-229, with further references.

72 UK Copyright, Designs and Patents Act 1988, s. 9 (1), § 7 German Urheberrechtsgesetz 1965, French Code de la Propriété Intellectuelle 1992, art. L. 111-3.

73 E.g. Michal Koščík and Matěj Myška, 'Database authorship and ownership of sui generis database rights in data-driven research', (2017) 31(1) International Review of Law, Computers \& Technology, 46-54.

74 E.g. Nuno de Araújo Sousa e Silva, The Ownership Problems of Overlaps in European Intellectual Property (Nomos Verlagsgesellschaft, 2014) 19-20. work as copyright- property object, and subject to the respective different rules, as has been discussed before.

27 Data (if they are not just data per se) could be copyright-protected under certain circumstances, particularly if they are software. Besides, independent of a potential copyright protection, one could introduce a sui generis data property right. However, the different aims of copyright and of a possible data-ownership protection appear in the different ownership orientation. In case of copyright, the copyright owner is (initially at least if copyright can be assigned at all) the author, the maker of the copyright work, such as the writer of the novel, the composer of the piece of music, the maker of the database (where the database under its sui generis protection of the database right is additionally copyright-protected $)^{75}$ or the programmer of the software. ${ }^{76}$ The idea of the protection is that the author can reap commercially the benefits of his or her work without undercutting and parasitical competition by competitors (the competition protection-oriented copyright approach) or that the personality of the author which is reflected in the work that he or she creates is protected (also) through the protection of that work (the personalityprotection approach of author's rights). ${ }^{77}$

28 However, in the case of possible data ownership, the matter is different. Here the originator, creator, collector or controller of the data, ${ }^{78}$ to follow the terminology of the General Data Protection Regulation (GDPR) ${ }^{79}$ who would be the owner of the data if the copyright model were followed, is, from a legal policy perspective, often not the preferred entitled person who could exercise (quasi) ownership rights over the data. The data 'owner' should rather be the data subject, ${ }^{80}$ that is, the person in relation to whom personal data have been generated, processed and collected, but not the person who has generated

75 See UK Copyright, Designs and Patents Act 1988, s. 3A (2).

76 UK Copyright, Designs and Patents Act 1988, ss. 3(1)(b), 9, $\S \S 7,69 \mathrm{a}$ (3) German Urheberrechtsgesetz 1965.

77 Rahmatian, Copyright and Creativity (n 26) 35, 47.

78 Often with a 'processor' of data as the controller's agent.

79 Regulation (EU) 2016/679 of the European Parliament and of the Council of 27 April 2016 on the protection of natural persons with regard to the processing of personal data and on the free movement of such data, and repealing Directive 95/46/EC (General Data Protection Regulation), 4. 5. 2016 OJ L 119/1, art 4 (7).

80 General Data Protection Regulation, Art 6 (1) (a), Art. 9 (1), Art. 13 and Recital 7; Banterle (n 25) 212. 
the data (controller) or has had generated the data for him (through a processor as agent) as the "dataauthor' in copyright terminology ${ }^{81}$ In the case of data ownership, it does not matter who 'created' the personal data, what matters is who is affected by the data. The originator and generator of sensitive health data may be the doctor who diagnoses a heart disease, but the patient should be the beneficiary of a data ownership right, which he can then exercise to prevent the data from being passed on to his life insurance company. The GDPR takes this view in several provisions, ${ }^{82}$ though from a public lawregulatory perspective, not as an instance of a private-law concept of ownership with the owner's rights to use and to exclude which derive from that ownership right..$^{83}$

29 There can also be a conflict between an existing copyright the data controller may have (as a result of electronic database and software-based data processing) and the rights of a data subject as a sui generis data owner. The GDPR briefly refers to such a conflict in Recital (63) and states that copyright and other intellectual property rights, while preserved in principle, cannot be used to prevent per se the data subject's right of access to personal data. ${ }^{84}$ The issue as to whether, and to what extent, copyright can protect data, is a complicated one: data per se cannot attract copyright protection - they are information or 'ideas' in the system of copyright, ${ }^{85}$ although even information could get protection to a limited extent now if it qualifies as online use of parts of press publications ${ }^{86}$ However, data collections, by virtue

81 Particularly if Anglo-Saxon copyright philosophy were followed, then the processor of data would probably not be 'owner' of such data, because he processes the data on behalf of the controller, being an analogy to the 'works made for hire'-doctrine in the USA, see US Copyright Act 1976, 17 USC §§ 101, 201 (b).

82 Regulation (EU) 2016/679 (General Data Protection Regulation), arts. 13, 15, 16, 17, 18, 20 and 21.

83 See above under (ii).

84 Regulation (EU) 2016/679 (General Data Protection Regulation), Recital (63): '[The data subject's right of access to personal data] should not adversely affect the rights or freedoms of others, including trade secrets or intellectual property and in particular the copyright protecting the software. However, the result of those considerations should not be a refusal to provide all information to the data subject.'

85 See e.g. Contreras (n 48) 630-631, for US law.

86 Directive (EU) 2019/790 of the European Parliament and of the Council of 17 April 2019 on copyright and related rights in the Digital Single Market and amending Directives 96/9/ of their selection and arrangement, can be protected under copyright if they fulfil the copyright/author's right originality requirement of the jurisdiction in question, or under database right if they constitute the database author's 'own intellectual creation'. ${ }^{87}$ The extent to which the data subject (or data owner in a sui generis data ownership conception) can prevail over such conflicting intellectual property rights is ultimately an issue of weighing the incompatible interests against each other under constitutional law and to allow a proportionate restriction of the ownership right of intellectual property in favour of the public law right of data access or private law right of sui generis data ownership. Rights of freedom of expression which prevail over copyright and confidential information are familiar examples of such a conflict. ${ }^{88}$

30 (iv) If sui generis data ownership is recognised, the right to use will involve the right to transfer data under this ownership right. The transfer of data ownership within the system of existing private laws can lead to certain difficulties, particularly if one envisages a harmonised approach at least across Europe. However, such an approach is practically inevitable because the common use of data invariably entails data transfer, and, in contrast to land, the incorporeal nature of data makes a restriction to any one national jurisdiction impossible. Intellectual property rights show a similar characteristic and therefore have a long tradition of international harmonisation, for example by the TRIPS Agreement. ${ }^{89}$ A transfer of data in accordance with ordinary property transfer rules would force the data ownership transfer to comply with the specific different national systems of ownership transfer, notably, the abstract transfer of ownership or abstract real conveyance (Germany, Greece), or the causal transfer of ownership (Austria, Switzerland, Hungary etc.), or the consensual transfer of ownership (France, Belgium, Italy, and effectively also England within the scope of the Sale of Goods Act 1979), ${ }^{90}$ whereby the consensual

EC and 2001/29/EC, OJ L 130, Art. 15, and Recital (58).

87 Directive 96/9/EC of the European Parliament and of the Council of 11 March 1996 on the legal protection of Databases, OJ L 77, Art. 3 (1). See also Banterle (2020: 206210).

88 For the UK, for example, see Lionel Bently, Brad Sherman, Dev Gangjee, Phillip Johnson, Intellectual Property Law (5th edn) (Oxford University Press, 2018) 257, 1256.

89 Agreement On Trade-Related Aspects of Intellectual Property Rights 1995 (TRIPS Agreement).

90 UK Sale of Goods Act 1979, ss. 17, 18 rule 1. This provision also applies in Scotland. 
transfer of ownership is arguably a subset of the causal ownership transfer. ${ }^{91}$ One can test the transfer method of data ownership in the light of these different national legal traditions, ${ }^{92}$ but it is more expedient to stipulate a sui generis transfer method for data ownership. There is a perfect precedent for a separate transfer regime for incorporeal property: the transfer or assignment of intellectual property rights, for example the transfer of a trade mark to a new owner, ${ }^{93}$ or the assignment of copyright, ${ }^{94}$ where that is possible. ${ }^{95}$

31 Such a suigeneris transfer method for data ownership could perhaps be provided in a harmonising instrument, such as an EU-Directive. It is not certain whether there are problems of competence of EU legislation in this regard, because property is an exclusive matter for the EU Member States. ${ }^{96}$ That seems to be undisputable in relation to land (immoveable property), but with regard to intellectual property the issue is far less clear. There is a harmonising Trade Mark Directive $e^{97}$ which does regulate trade mark transfers (with reference to national procedures for recording the transfers in the Member States' registers, and

91 Rahmatian, German Moveable Property (n 51) 217, 219.

92 Andreas Boerding, Nicolai Culik, Christian Doepke, Thomas Hoeren, Tim Juelicher, Charlotte Roettgen, Max V. Schoenfeld, 'Data Ownership - A Property Rights Approach from a European Perspective', (2018) 11 (2) Journal of Civil Law Studies, 342-346, 352-354.

93 E.g.UK Trade Marks Act 1994,s. 24; § 27 German Markengesetz 1994; French Code de La Propriété Intellectuelle 1992, art. L. 714-1.

94 UK Copyright, Designs and Patents Act 1988, s. 90; French Code de La Propriété Intellectuelle 1992, art. L. 131-3 and art. L. 131-4; Michel Vivant and Jean-Michel Bruguière, Droit d'auteur et droits voisins, $2^{\text {nd }} e d$. (Dalloz, 2013) 672. On the distinction between cession and licence in French author's rights law and its relative unimportance (compared to the UK), see Rahmatian, Copyright and Creativity (n 26) 205-208, with further references.

95 An assignment of the author's right is not possible in Germany or Austria because of their monist systems of author's right, see Germany, \$ 29 Urheberrechtsgesetz 1965, Austria, § 23 (3) Urheberrechtsgesetz 1936. On the monist system of author's rights in the context of assignments, see Rahmatian, Copyright and Creativity (n 26) 49-51, 206-207.

This concern has been raised by Boerding et al. (n 92) 353.

97 Directive (EU) 2015/2436 of the European Parliament and of the Council of 16 December 2015 to approximate the laws of the Member States relating to trade marks (Text with EEA relevance), OJ L 336, p. 1-26. these are essentially the same) - and trade marks are unquestionably property. ${ }^{98}$ Furthermore, the Trade Mark Regulation invents the creature of the EU trade mark which is an EU-property right (and the regulation obviously also contains trade mark transfer rules, including the formality requirement of registration of the transfer). ${ }^{99}$ For the possible proprietary nature of data and their transfer as property, the role model is more the trade mark than land, one would think. The dematerialised property concept rejects the tangible nature of some forms of property as a blueprint for all property rights at any rate. The method of concluding an international treaty between the EU Member States outside EU law to overcome jurisdictional problems ('enhanced cooperation'), as has been done for the envisaged unified patent court system (Unified Patent Court Agreement), ${ }^{100}$ is also an option, but a controversial one. ${ }^{101}$ However, the future of the unified patent and its court system is in doubt at the moment anyway. ${ }^{102}$

32 The rules for the derivative acquisition of ownership are in fact directed more towards tangible property, so that transfer rules for incorporeal property, such as for the assignment of debts or the transfer of negotiable instruments, would be a more appropriate role model. In addition, although the abstract/causal/

98 ibid, art. 22.

99 Council Regulation (EC) No 207/2009 of 26 February 2009 on the European Union trade mark, OJ L 078, 24.3.2009, p.1, art. 17.

100 Agreement on a Unified Patent Court, OJ C 175, 20. 6. 2013, p. 1-40, following the Regulation (EU) No $1257 / 2012$ of the European Parliament and of the Council of 17 December 2012 implementing enhanced cooperation in the area of the creation of unitary patent protection, OJEU L 361, 31. 12. 2012, p. 1.

101 Legal challenges against this form of law making by Italy and Spain, see CJEU C-274/11 and C-395/11 Spain and Italy v. Council. They were unsuccessful, ibid, paras. 36-37, 68, 77, 82-83, 92.

102 This is not so much because the UK after Brexit (as from 1 February 2020) decided not to cooperate, see 'The Unified Patent Court after Brexit', (European Parliament, At A Glance, JURI Committee) Policy Department for Citizens' Rights and Constitutional Affairs PE 649.575, March 2020, available at: https://www.europarl.europa.eu/RegData/ etudes/ATAG/2020/649575/IPOL_ATA(2020)649575_EN.pdf (accessed 16 April 2020). More problematic is that the German Constitutional Court rejected the adopted process of the accession of Germany to the Unified Patent Court system as unconstitutional, see German Bundesverfassungsgericht, Beschluss des Zweiten Senats vom 13. Februar 2020 - 2 BvR $739 / 17$ (issued 20 March 2020). The current coronavirus crisis will delay further a possible solution. 
consensual conveyance rules may be preserved technically in the case of the assignment of claims (debts), their actual realisation is rather merely notional. The causal conveyance as one version of ownership transfer may serve as an example. In Austria, ownership transfer requires a contract (title) directed at the transfer of ownership (such as a sale) and a traditio, the (actual or symbolical) delivery of the property in question to the acquirer (conveyance) to effect an ownership transfer (causal conveyance). ${ }^{103}$ The assignment of debts (Zession) theoretically follows this principle in Austrian law, ${ }^{104}$ but the contract (the assignment agreement) and the conveyance (the actual assignment or cession) fall into one act in reality, particularly since the assignment itself can be effected without any formalities, only that it becomes enforceable against the debtor once the assignment has been intimated to him..$^{105}$ Theoretically this process complies with the principle of the contract as the necessary cause for the validity of the conveyance, but that amounts to a doctrinal legal reinterpretation without becoming apparent (or relevant) in social reality. A practical solution for the transfer of data ownership would be, as a constitutive formality rule, a written instrument signed by the owner and transferor of the data to effect a valid transfer of data ownership, similar to the assignment of copyright provision in the UK..$^{106}$

\section{Digitised objects}

33 From an IT-perspective, digitised objects also constitute a form of data, but from a property theorist's perspective, they are theoretically a creation of a separate virtual (that is, incorporeally represented) res from a tangible prototype, thus, for example, a painting or a letter and the digitisation of it. For the idea of dematerialised property the difference only refers to the reifier, not to the concept itself. However, the digitised copy would hardly become the object of separate copyright protection (or perhaps neighbouring rights protection in author's rights countries), because usually there would not be more than format-shifting copying or reproduction (from paper to electronic digitisation) which could not attract separate copyright. The matter is not entirely clear-cut, because the English courts have given copyright protection to a photograph

$103 \S 380$ Austrian ABGB.

104 E.g. Helmut Koziol and Rudolf Welser, Grundriß des bürgerlichen Rechts, Vol 1: Allgemeiner Teil und Schuldrecht, 9th ed. (Manz Verlag, 1992), 292. taken from a picture in Graves' Case, ${ }^{107}$ and it is not a far-stretching legal analogy to consider digitised copies as equivalent to photographs. Whether Graves' Case has survived the ruling of the CJEU in Painer $^{108}$ and in similar cases, ${ }^{109}$ is however doubtful (and in turn, it is not predictable if and how CJEUjudgments remain relevant as persuasive authority in Britain after Brexit). In any case, if the digitised copy achieves the required European originality standard of "own intellectual creation' ${ }^{110}$ (that could be difficult in practice for mere digitisations), then it will obtain copyright protection in its own right. If, however, the digitisation cannot be brought under an intellectual property right (copyright) at all, then it is not a res, but a nullum, in law, because the real right creates the thing. ${ }^{111}$ There may be unfair competition protection remedies for such digitised copies in continental European countries, such as Germany and Austria ('ergänzender Leistungsschutz', 'Ausbeutung', a protection against parasitical freeride), ${ }_{112}$ but these remedies do not create or confer a real right, so there is still no res.

34 However, if there is a selection or arrangement of digitised copies, there can be protection by a database right ${ }^{113}$ and, if an underlying software is involved, separate copyright protection for that software would apply, ${ }^{114}$ though not for the single digitised object (copy). The potentially disconcerting

107 Graves' Case (1869) LR 4 QB 715.

108 Painer v. Standard Verlags GmbH, Axel Springer AG, Süddeutsche Zeitung GmbH, Spiegel-Verlag Rudolf Augstein GmbH \& Co. KG, Verlag M. DuMont Schauberg Expedition der Kölnischen Zeitung GmbH \& Co KG (C-145/10).

109 The first of its kind was Infopaq International v. Danske Dagblades Forening (C-5/08).

110 Painer v. Standard Verlags $\mathrm{GmbH}$ and others (C-145/10) paras. 86-92.

111 See above under $B$.

112 Germany: § 4 (3) UWG 2004 (Gesetz gegen den unlauteren Wettbewerb, Unfair Competition Act), and Horst-Peter Götting, Gewerblicher Rechtsschutz, 9th ed. (C. H. Beck, 2010) 74-75; Austria §1 (1) (1) UWG 1984 (Gesetz gegen den unlauteren Wettbewerb, Unfair Competition Act), and Andreas Wiebe et al., Wettbewerbs- und Immaterialgüterrecht, 4th ed. (Facultas Verlag, 2018) 332-333.

113 Directive 96/9/EC of the European Parliament and of the Council of 11 March 1996 on the legal protection of Databases, OJ L 77, Art. 1 (1) and (2).

114 Directive 2009/24/EC of the European Parliament and of the Council of 23 April 2009 on the legal protection of computer programs (codified version), OJ L 111, Art. 1 (1) and (3). 
aspect of this protection regime is that a prototype, which is in the public domain itself (for example a baroque painting) can be 'cocooned' by layers of protection for the digitised version, so that the original is effectively dragged out of the public domain and covered by copyright, particularly if access to the original work is in reality only made possible through the digitised copy. The prohibition of the circumvention of technological measures against copying in the Information Society Directive ${ }^{115}$ reinforces this effect.

\section{E. Conclusion}

35 Debts, money, intellectual property, and - to the extent to which one is able to or wants to recognise property rights in them - data and digitised objects, are all versions of the general principle of dematerialised property. Property is a normative creation, it is not dependent on, or attaches to, a physical object in the real world - that is conceptually irrelevant. 'Property' is a creature of the law: the exclusive rights to a thing or res, the property rights or real rights, actually create the property or res by protecting it erga omnes. The physical objects in the natural world (natural or man-made ones) are only recognised by, and incorporated in, the system of the law by attaching property rights to them: only then they are objects or 'things' for the purpose of the law, otherwise they are non-existent for the law. An intangible object, such as an intellectual property right, is also created by the law, but there is no physical object which represents this res, at least not directly. Again, the law (qua property rights) creates the thing, here one with no physical manifestation. The same idea can be applied to data if one wants to establish a concept of data ownership. However, that is ultimately a decision of legal policy, not of property law and legal theory.

115 Directive 2001/29/EC of the European Parliament and of the Council of 22 May 2001 on the harmonisation of certain aspects of copyright and related rights in the information society, OJ L 167, Art. 6. 